\title{
Perencanaan Komunikasi Program Studi Ilmu Komunikasi Fakultas Ilmu Sosial dan Ilmu Politik UIN Raden Fatah Palembang
}

\author{
Ainur Ropik \\ Fakultas Ilmu Sosial dan Ilmu Politik \\ Universitas Islam Negeri Raden Fatah Palembang, Indonesia \\ Email: ainurropik_uin@radenfatah.ac.id
}

\begin{abstract}
Abstrak
Penelitian ini meneliti mengenai Perencanaan Komuniasi Program Studi Ilmu Komunikasi Fakultas Ilmu Sosial dan Ilmu Politik Universitas Islam Raden Fatah Palembang, dengan tujuan antara lain: untuk mendeskripsikan bagaimana pola perencanaan komunikasi yang dilakukan untuk memperoleh dukungan semua pihak dalam mewujudkan visi bersama Metode penelitian ini menggunakan metode kualitatif dengan analisis SWOT. Perencanaan Komunikasi adalah bagian dari manajemen strategis yang merencanakan secara terus menerus untuk setiap infrastruktur komunikasi; komunikator, pesan, media, khalayak dan evaluasi umpan balik secara tepat. Hasil akhir dari proses perencanaan komunikasi adalah semakin menguatkan citra positif dan kepercayaan khalayak pada Program Studi Ilmu Komunikasi. Namun kondisi objektif perencanaan komunikasi di lingkungan Program Studi Ilmu Komunikasi belum berjalan dengan baik, sehingga perlu diambil langkah-langkah antara lain: 1) Peningkatkan ethos komunikator yang notabene sebagai source credibility di Program Studi Ilmu Komunikasi masih jauh dari kondisi ideal yang diharapkan. 2) Mengomunikasikan pesan-pesan dari program komunikasi harus dilakukan secara terus menerus dan berkesinambungan. Terutama pesan-pesan yang bisa memengaruhi khalayak untuk mengubah perilaku dan tindakan sesuai dengan tujuan Program Studi. 3) Melakukan optimalisasi potensi-potensi media yang ada untuk digunakan dalam proses komunikasi kepada khalayak luas. Mengingat pentingnya optimalisasi media, dipandang perlu untuk menunjuk petugas khusus yang bekerja untuk mengelolah media dan membagun media relations. 4) Membangun hubungan yang baik dengan khalayak internal dan eksternal. Meminimalisir potensi yang akan membuat khalayak kecewa.
\end{abstract}

Kata Kunci: Analisis SWOT, Strategi, Perencanaan Komunikasi

Dalam proses mencapai tujuan sebuah organisasi, biasanya pimpinan dan anggota organisasi sering terjebak pada kebiasaan klasik yakni fokus menjalankan peran dan fungsi serta pembagian tugas (job description) masing-masing dalam mencapai tujuan yang telah ditetapkan bersama. Dengan menjalankan semua peran

Intizar, Volume 23, Nomor 2, 2017 
dan fungsi serta tugas tersebut memang ada yang bisa membawa perubahan pada sebuah organisasi, namun kebanyakan sebuah oraganisasi tidak dapat bertahan lama. Menurut Tyson \& Jackson (2001) organisasi kerja merupakan sebuah sumber identitas, forum untuk mengeksplorasi emosi, tempat untuk menghadirkan logika, melayani tujuan-tujuan ekonomis, tetapi semuanya merupakan bentukan manusia. Kantor, rumah sakit, toko, sekolah, tak terkecuali universitas dan lingkup organisasi di dalamnya seperti organisasi fakultas dan program studi merupakan tempat sukses dan kegagalan, tempat pengasingan atau pemenuhan, tempat orang-orang yang mendapatkan pengalaman sosial yang paling mengerikan atau pengalaman paling indah.

Terkait dengan itu, bahwa semua kondisi dalam sebuah organisasi adalah bentukan manusia. Kegagalan, keberhasilan, kebanggaan, suasana menyenangkan bahkan yang membosankan adalah bagian dari akibat tindakan-tindakan yang dibuat oleh anggota organisasinya sendiri. Dengan kata lain, manusialah yang merencanakan apa pun tentang sesuatu yang dihasilkan.

Selama ini, kata perencanaan, khususnya dalam lingkungan perencanaan birokrat, masih dianggap pekerjaan kurang penting, buang waktu, bahkan hanya sekedar tarik-menarik kepentingan. Ada beberapa penyebab yang memunculkan pemikiran demikian, yakni menyangkut kekeliruan yang seringkali menjadi kebiasaan para perencana, misalnya: perencanaan hanya sekedar membuat dokumen rencana (konvensional). Bahkan hanya sekedar dokumen untuk mencairkan anggaran. Selanjutnya, perencanaan hanya dianggap suatu kegiatan yang dilakukan sesekali saja dan cenderung memunculkan ego sektoral dan menjauhi upaya sinergitas perencanaan antar sektor atau bidang. Hal inilah yang menyebabkan kegiatan perencanaan banyak dijauhi dan malas untuk dikembangkan secara baik dalam menyelesaikan persoalan.

Ketika semua konsep perencanaan itu masuk dalam bidang tindakan manusia atau sekelompok manusia, maka akan ditemukan konsep yang baru yang menghasilkan dimensi perencanaan yang spesifik. Jika kata perencanaan itu diintegrasikan dengan ekonomi, muncul perencanaan ekonomi, politik muncul perencanaan politik, dan jika berintegrasi dengan perubahan sosial dan pembentukan citra sosial melalui instrumen komunikasi maka perencanaan masuk ke dalam ranah perencanaan komunikasi.

Perencanaan komunikasi adalah proses pengalokasian sumber daya komunikasi untuk mencapai tujuan organisasi. Sumber daya tersebut tidak hanya mencakup media massa dan komunikasi antarpribadi, tapi juga setiap aktivitas yang 
dirancang untuk mengubah perilaku dan menciptakan keterampilan-keterampilan tertentu di antara individu dan kelompok dalam lingkup tugas-tugas yang dibebankan oleh organisasi (Cangara, 2013, hal. 45).

Dapat dipahami bahwa tujuan perencanaan komunikasi adalah sebuah proses untuk memengaruhi khalayak dengan cara mengoptimalkan semua sumber daya komunikasi dengan menetapkan kebijakan komunikasi yang akan dijalankan. Sedangkan khalayak bukan hanya orang-orang yang berada di luar organisasi, tetapi justru yang paling penting dalam proses perencanaan komunikasi adalah menyasar khalayak internal sebuah organisasi. Sebab, orang-orang yang ada di dalam internal organisasi merupakan simbol yang bisa memengaruhi citra organisasi. Perilaku seorang anggota organisasi ketika dia berada di luar organisasi akan dipandang orang luar sebagai cerminan organisasi di mana tempat seseorang berkembang.

Merealisasikan kebijakan komunikasi kampus agar bisa memengaruhi prilaku dan persepsi khalayak luas adalah aktivitas komunikasi yang harus dilakukan, namun tentu harus mendahulukan pada kebijakan komunikasi dengan publik internal seperti mahasiswa. Banyak kampus yang menganggap sepele pada perencanaan komunikasi kepada salah satu khalayak internal tersebut. Padahal usaha untuk memengaruhi prilaku dan idenditas mereka menjadi sangat penting. Publik eksternal terlebih dahulu akan menerima pesan/simbol yang dikomunikasikan mahasiswa (publik internal) kepada mereka. Baik dan buruk simbol yang menjadi identitas mahasiswa tentu juga akan memengaruhi persepsi publik eksternal pada citra oraganisasi (kampus).

Produk perencanaan komunikasi yang paling dasar adalah gambaran atau tujuan yang akan dicapai organisasi yang biasanya akan terangkum secara filosofis dalam bentuk visi. Oleh sebab itu, tolok ukur keberhasilan sebuah perencanaan komunikasi pada pesan visi adalah semua anggota organisasi secara sadar mampu memaknai dan menerjemahkannya dalam bentuk prilaku dan tindakan dalam oraganisasi, tentu untuk mewujudkan tujuan bersama dalam organisasi. Jika anggota organisasi tidak mampu memaknai tujuan organisasi dan menjadikan tujuan tersebut sebagai kerangka bertindak dan berprilaku maka organisasi akan mengalami kendala untuk mencapai tujuan bersama.

Seperti contoh mahasiswa program studi ilmu komunikasi misalnya, ketika ditanya apa alasan mengambil jurusan ilmu komunikasi pada program studi Ilmu Komunikasi di Fakultas Ilmu Sosial dan Politik Universitas Islam Negeri Raden Fatah, rata-rata jawaban yang ditemukan sama, yakni karena tidak lulus seleksi pada program studi lain. Seolah jurusan Ilmu Komunikasi adalah jurusan pelarian atau 
alternatif kedua dan ketiga. Selain itu, ketika ditanya tentang keilmuan komunikasi masih banyak juga yang bingung tentang apa sebenarnya komunikasi. Terlebih jika ditanya seputar visi dan misi program studi Ilmu Komunikasi, hampir dipastikan tidak satu pun mahasiswa hafal atau bahkan mengetahui garis besarnya.

Berangkat dari latar belakang tersebut, peneliti melihat ada suatu realitas yang menarik dikaji lebih dalam mengenai perenanaan komunikasi yang sudah dilakukan oleh Prodi Ilmu Komunikasi yang notabene adalah pekerjaan orang-orang komunikasi.

\section{Perencanaan Komunikasi Program Studi Ilmu Komunikasi}

\section{Menetapkankan Komunikator}

Seperti yang sudah dijelaskan pada bab sebelumnya, dalam berbagai kajian komunikasi, komunikator menjadi sumber dan kendali bagi semua aktivitas komunikasi. Karena itu jika suatu proses komunikasi tidak berhasil dengan baik, maka kesalahan utama bersumber dari komunikator, karena komunikatorlah yang tidak memahami penyusunan pesan, memilih media yang tepat, dan mendekati khalayak yang menjadi target sasaran. Sebagai pelaku utama dalam aktivitas komunikasi, komunikator memegang peranan yang sangat penting. Untuk seorang komunikator yang akan bertindak sebagai ujung tombak suatu program harus terampil berkomunikasi, kaya ide, serta penuh daya kreativitas.

Jika ada pertanyaan siapa sebenarnya komunikator Prodi Ilmu Komunikasi Fakultas Ilmu Sosial dan Ilmu Politik Universitas Islam Negeri Raden Fatah Palembang, maka jawabannya adalah semua yang tergabung di dalam Prodi Ilmu Komunikasi adalah komunikator. Mulai dari mahasiswa, tenaga pendidik, tenaga kependidikan, admin, petugas keamanan bahkan tenaga kebersihan adalah komunikator bagi Prodi Ilmu Komunikasi. Merekalah sebetulnya yang bertugas melakukan perencanaan komunikasi secara kontinu agar bisa menghasilkan dan membagun citra yang baik di benak khalayak (stakeholder).

Dalam rekrutmen komunikator yang ada di Instansi/Lembaga Negeri tentu sangat berbeda dengan pola rekrutmen komunikator Instansi/Lembaga Swasta. Pola rekrutmen komunikator pada lembaga swasta akan lebih bebas, terukur dan sesuai dengan ketentuan lembaga yang tersinergi dengan visi lembaga/instansi tersebut untuk mencapai tujuannya. Aspek penampilan yang menarik, kreativitas, kemampuan dan profesionalisme serta komitmen untuk mewujudkan visi lembaga sangat ditekankan. Tidak sama dengan lembaga atau instansi pemerintahan yang pola rekrutmennya fokus pada seleksi tes tertulis dan wawancara. Itu sebabnya 
lembaga pemerintahan akan sulit membangun citra, karena lebih menekankan aspek $I Q$ ketimbang aspek lainya.

Jika ingin ideal, pola rekrutmen mahasiswa komunikasi harusnya tidak sebatas pada lulusnya mengikuti seleksi tertulis, tetapi juga harus mengikuti seleksi-seleksi berikutnya, misalnya wawancara, tes kemampuan bakat dan bahasa yang sesuai dengan bidang komunikasi. Sehingga akan menghasilkan calon mahasiswa/komunikator yang baik untuk Prodi Ilmu Komunikasi. Sebab merekalah yang akan bertugas menjadi Public Relations-nya Program Studi. Merekalah yang sangat memengaruhi berhasil atau tidaknya Program Studi untuk bisa dikenal di mata publik luas.

Dari semua informan yang diwawancarai, ditemukan mayoritas mahasiswa bahkan tidak menyadari bahwa seyogianya mereka adalah seorang komunikator untuk Prodi Komunikasi. Ada banyak juga justru masuk jurusan Ilmu Komunikasi tanpa disengaja, dengan kata lain banyak yang mengambil jurusan Ilmu Komunikasi karena menyangka bahwa jurusan tersebut memperajari tentang ilmu komputer. Seperti yang disampaikan oleh Ahmad Saidun berikut:"Dulunya pas milih jurusan dikira komputer ternyata salah jurusan dan dijalani aja dulu siapa tau cocok."

Begitu juga dengan Destri, "Komunikasi pilihan ke dua karna gak lulus di pilihan pertama psikologi tapi gak lulus." Ada juga jawaban yang hampir sama, seperti yang disampaikan oleh Farid, "Sudah bingung ambil jurusan di Unsri gak da yang lulus, yasudah pas buka web di UIN buka pendaftaran dan akhirnya pilih komunikasi, pas lulus gak tau juga bakal belajar apa, prospeknya apa cuman ya dicoba aja."

Dari jawaban informan tersebut dapat dipahami bahwa banyak juga informan yang "coba-coba" bergabung di Prodi Ilmu Komunikasi. Prodi Ilmu Komunikasi acapkali menjadi tampungan untuk mahasiswa yang mengganggap Ilmu Komunikasi adalah Ilmu Komputer atau hanya sekedar pilihan terakhir setelah tidak lulus dengan pilihan jurusan yang memang diminati. Meskipun ada sedikit yang sudah memahami apa sebetulnya jurusan Ilmu Komunikasi, misalnya informan Ajeng berikut: "Sebelumnya pernah jadi penyiar, jadi masuk komunikasi ini pengen lebih tau dunia komunikasi yang lebih dalam lagi. Bangga, karena peminat komunikasi itu banyak, jadi klo masuknya komunikasi saya bangga karena sesuai dengan keinginan".

Juga seperti yang diungkapkan Hafidz, "Saya sih sudah niat dari awal untuk masuk komunikasi, di samping memang disupport sama bapak. Saya rasa udah benar-benar mendarah daging jiwa komunikasi. Dan alhamdulillah udah 
banyak prestasi dari semakin menyukai dunia komunikasi, sudah pernah juara film dokumenter tingkat nasional dan bisa jalan-jalan ke Shanghai. Jadi youtuber dan aktif di media sosial, organisasi juga."

Bisa ditarik kesimpulan juga bahwa ada beberapa informan yang bergabung di Prodi Ilmu komunikasi atas pilihan yang berangkat dari minat dan niat. Komunikator yang seperti mereka yang memang dibutuhkan untuk mengembangkan Prodi Ilmu Komunikasi.

Ada tiga syarat yang harus dipenuhi seorang komunikator, yakni: (1) tingkat kepercayaan orang lain kepada dirinya (kredibilitas), (2) daya tarik (attractive), dan kekuatan (power). Kredibilitas adalah perangkat persepsi tentang kelebihankelebihan yang dimiliki seorang komunikator sehingga bisa diterima oleh target sasaran. Josep Gobbel, Menteri Propaganda Hitler dalam Perang Dunia II menyatakan bahwa untuk menjadi seorang komunikator yang andal dan efektif harus memiliki kredibilitas yang tinggi di mata pendengar. Kredibilitas menurut Aristoteles, bisa diperoleh jika seorang komunikator memiliki ethos, pathos, dan logos. Ethos menunjukkan karakter kepribadian seseorang sehingga ucapanucapannya dapat dipercaya. Pathos ialah kekuatan yang dimiliki seorang komunikator dalam mengendalikan emosi pendengarnya, sedangkan logos ialah kekuatan yang dimiliki seorang komunikator melalui argumentasinya.

James McCroskey (1966) lebih jauh lagi menjelaskan bahwa kredibilitas seseorang komunikator dapat diperoleh dari kompetensi (competence), sikap (attitude), tujuan (intention), kepribadian (personality), dan dinamika (dynamism). Kompetensi ialah penguasaan yang dimiliki seorang komunikator pada masalah yang dibahasnya. Seorang dokter misalnya lebih berkompeten bicara tentang kesehatan daripada seorang insinyur pertanian. Sikap menunjukkan pribadi pembicara apakah ia tegas atau toleran dalam prinsip, tujuan menunjukkan apa yang disampaikan itu punya maksud yang baik atau tidak. Kepribadian menunjukkan apakah pembicara memiliki pribadi yang hangat dan bersahabat, sedangkan dinamika menunjukkan apakah materi yang disampaikan itu menarik atau membosankan.

Jadi, seorang komunikator menjadi source of credibility disebabkan adanya "ethos" pada dirinya, yaitu apa yang dikatakan oleh Aristoteles, dan yang hingga kini tetap dijadikan pedoman adalah good sense, good moral character and goodwill, yang oleh para cendekiawan modern diterjemahkan menjadi itikad baik (good intentions), dapat dipercaya (trustworthiness), dan kecakapan atau kemampuan (competence or expertness). 
Termasuk ethos komunikator ialah sikap mentalnya yang tercerminkan dalam tingkah lakunya sebagaimana digambarkan secara skematik oleh Prof. Harry Ingham yang terkenal sebagai Johari Window (Luft \& Ingham, 1961).

\begin{tabular}{|l|l|}
\hline I & II \\
OPEN AREA & BLIND AREA \\
Known by ourselves and Known by & $\begin{array}{l}\text { Known by others not Known by } \\
\text { ourselves }\end{array}$ \\
\hline $\begin{array}{l}\text { III } \\
\text { HIDDEN AREA }\end{array}$ & IV \\
$\begin{array}{l}\text { Known by ourselves but not known by } \\
\text { others }\end{array}$ & $\begin{array}{l}\text { Not known by ourselves and not known } \\
\text { by others }\end{array}$ \\
\hline
\end{tabular}

Berdasarkan konsep Johari Window tersebut, tingkah laku komunikator dapat terlihat secara skematis pada gambar tersebut di atas.

Area I, yakni Open Area atau Bidang Terbuka yang menunjukkan bahwa kegiatan yang dilakukan oleh komunikator disadari sepenuhnya oleh yang bersangkutan, juga oleh orang lain; ini berarti adanya keterbukaan, atau dengan kata lain tidak ada yang disembunyikan kepada orang lain. Area II, Blind Area atau Bidang Buta menggambarkan bahwa perbuatan komunikator diketahui oleh orang lain, tetapi dirinya sendiri tidak menyadari apa yang dia lakukan. Area III, Hidden Area atau Bidang Tersembunyi adalah kebalikan dari Area II, yakni bahwa yang dilakukan komunikator disadari sepenuhnya olehnya, tetapi orang lain tidak dapat mengetahuinya. Ini berarti bahwa komunikator bersikap tertutup, ia merasaa bahwa apa yang dilakukannya tidak perlu diketahui oleh orang lain. Area IV, Unknown Area atau Bidang Tak Dikenal adalah menggambarkan bahwa tingkah laku komunikator tidak disadari oleh dirinya sendiri, tetapi juga tidak diketahui orang lain.

Seorang komunikator yang baik harus senantiasa menjaga ethosnya tidak turun, bahkan terus menaik. Ini ditentukan oleh mahir atau tidaknya ia berkomunikasi. Dalam hubungan ini perencanaan selalu sangat diperlukan. Karena itulah bagi seorang komunikator berlaku sebuah pemeo yang berbunyi: "Qui ascendit sine labore, Descendit sine honore," (Siapa yang naik tanpa kerja, akan turun tanpa kehormatan). Maknanya dalam hubungan dengan komunikasi, siapa yang berkomunikasi tanpa perencanaan, akan memperoleh kegagalan dalam berkomunikasi. 
Para dosen juga bertindak sebagai komunikator untuk mahasiswa di kelas atau di kampus. Sebagai seorang komunikator yang dianggap sudah memiliki kredibilitas, daya tarik dan kekuatan (power) diharapkan bisa membuat proses komunikasi dua arah dengan mahasiswa mampu mencapai tujuan Prodi Ilmu Komunikasi. Tujuan dari Prodi Ilmu Komunikasi adalah tergambar dalam visi Prodi Ilmu Komunikasi sendiri. Oleh sebab itu, sebagai komunikator, dosen harus secara konsisten menyampaikan pesan yang berhubungan dengan upaya mewujudkan visi Prodi. Bukan hanya sebatas dipahami oleh mahasiswa, tetapi juga menumbuhkan keinginan mahasiswa untuk mewujudkannya bersama. Dan indikasinya adalah terjadi perbahan sikap, penampilan, cara belajar, pengayaan keilmuan komunikasi yang tercermin dalam visi Prodi Ilmu Komunikasi.

Ada juga beberapa mahasiswa yang sudah menyadari bahwa setiap tindakan dia di tempat umum (ruang publik) akan menyampaikan pesan kepada orang lain sehingga harus selalu siap menampilkan pesan yang baik dan berupaya menghindari produksi pesan yang buruk, karena bagi mereka, bahwa tindakan dan keberadaan mereka dalam ruang publik akan menimbulkan banyak persepsi dan pada akhirnya akan menciptakan citra baik atau pun buruk baik untuk diri mereka sendiri maupun untuk institusi tempat mereka berkembang, tergantung pada pesan apa yang mereka sampaikan.

"Kita kan mahasiswa UIN, jadi sikap kita harus mencerminkan mahasiswa UIN, harus bisa baca Al-Qur'an, yang laki-laki harus bisa azan di masjid, jadi Imam, baca Yasin, harus ramah, sebab klo gak malulah sebagai mahasiswa UIN sama aja mencemarkan nama baik UIN."

"Sebagai mahasiswa Komunikasi saya suka bangga nunjukkin klo saya anak komunikasi, dengan bikin video, film-film pendek, ikut lomba-lomba yang ada hubungan dengan komunikasi, aktif juga di media sosial, biar bisa nunjukkin bahwa oh ini lo kegiatan yang bisa dilakukan oleh anak komunikasi, anak komunikasi itu pasti aktif, suka ngomong di depan orang, di depan kamera juga, jadi biar orang semakin tertarik masuk komunikasi."

Michael Kaye (Kuswarno, 2009, hal. 118) menyebutkan bahwa "what we must realise is that the heart of communication is not the surface but in the meanings of interpretations that we ascribe to the message." Menurut Kaye jantungnya komunikasi terletak pada makna atau interpretasi terhadap pesan. Selanjutnya Kaye mengungkapkan bahwa ketika pesan dipresentasikan seseorang, interpretasi terhadap pesan tersebut memengaruhi bagaimana orang tersebut harus memresntasikannya. Interaksi pesan, presentasi dan interpretasi membentuk 
p-ISSN: 1412-1697; e-ISSN: 2477-3816

http://jurnal.radenfatah.ac.id/index.php/intizar

karakter yang unik dalam proses komunikasi. Suatu makna (interpretasi stimuli) membentuk pola dasar tindakan dan perhatian komunikatif antara satu orang dengan orang lain. Pola dasar ini disebut sebagai "pilihan strategis." Pilihan strategis ini menjadi bagian penting bagi orang yang berkomunikasi dan persyaratan penting bagi kemampuan seseorang dalam berkomunikasi.

Konsep manajemen komunikasi menjelaskan bahwa kemampuan seseorang berkomunikasi tidak muncul begitu saja ketika dia lahir, melainkan hasil belajar dan mengembangkannya. Dengan demikian manajemen komunikasi adalah suatu istilah yang memberikan kontribusi terhadap pembentukan makna dalam masyarakat, misalnya dalam memaknai pesan orang lain atau gaya komunikasi orang lain. Dalam tindakan komunikasi yang terjadi pada seluruh komunikator Program Studi Ilmu Komunikasi tidak serta merta memiliki kemampuan dalam berkomunikasi yang khas ala akademisi komunikasi, bagaimana mereka mengemas penampilan diri, mengelola kesan agar tidak terlihat orang yang menguasai komunikasi adalah bagian dari pembelajaran dan pengembangan pola komunikasinya sendiri.

\section{Menentukan Pesan}

Dalam membahas pesan (message) dalam proses komunikasi, kita tidak bisa melepaskan diri dari apa yang disebut simbol dan kode, karena pesan yang dikirim komunikator kepada penerima terdiri atas rangkaian simbol dan kode. Dalam kehidupan kita sehari-hari, seringkali kita tidak bisa membedakan pengertian antara simbol dan kode. Bahkan banyak orang yang menyamakan kedua konsep itu. Menurut David K. Berlo (Cangara, 2013, hal. 112), simbol adalah lambang yang memiliki suatu objek, sementara kode adalah seperangkat simbol yang telah disusun secara sistematis dan teratur sehingga memiliki arti. Sebuah simbol yang tidak memiliki arti bukanlah kode.

Gedung kampus, kelas, sumber daya manusia (dosen, pegawai, mahasiswa dan lainnya) adalah simbol Universitas. Sedangkan simbol yang sudah disusun secara sistematis dan teratur seperti warna gedung, logo, penataan ruangan, lingkungan yang bersih, cara berpakaian dan bersikap adalah simbol yang menjadi kode dari semua orang yang berhubungan dengan simbol itu.

Kode pada dasarnya dapat dibedakan atas dua macam, yakni kode verbal (bahasa) dan kode nonverbal (isyarat). Kode verbal dalam pemakaiannya menggunakan bahasa. Bahasa dapat didefinisikan seperangkat kata yang telah disusun secara berstruktur sehingga menjadi himpunan kalimat yang mengandung arti. Selain menggunakan kode verbcal dalam komunikasi antarmanusia digunakan juga kode nonverbal yakni berupa isyarat.

Intizar, Volume 23, Nomor 2, 2017 
Studi Albert Mahrabian (1971) menjadi hal yang menarik dari studi kode nonverbal. Studi tertebut menyimpulkan bahwa tingkat kepercayaan dari pembicaraan orang hanya 7 persen berasal dari kode verbal, 38 persen dari vokal suara, dan 55 persen dari ekspresi muka. Ia juga menambahkan jika terjadi pertentangan antara apa yang diucapkan seseorang dengan perbuatannya, orang lain cenderung mempecayai hal-hal yang bersifat nonverbal.

Dalam hal perencanaan pesan yang dilakukan oleh program studi Ilmu Komunikasi meliputi perencanaan pesan bersifat verbal dan nonverbal. Perencanaan pesan bersifat verbal berupa bahasa yang diucapkan secara langsung pada saat peristiwa komunikasi terjadi, seperti pada saat sambutan seminar, orasi ketika OSPEK mahasiswa baru, proses percakapan pada saat pembelajaran di kelas, percakapan yang terjadi antara mahasiswa dengan admin, tanggapan pihak fakultas pada saat mahasiswa menggelar aksi demonstrasi, dan banyak lagi kegiatan percakapan lainnya. Selanjutnya adalah perencanaan yang bersifat nonverbal, mulai dari merumuskan pakaian yang harus dikenakan oleh mahasiswa, dosen dan karyawan, penataan kelas, pemilihan warna yang akan menjadi ciri khas program studi, tulisan visi misi yang dipajang lengkap dengan font dan warna yang dipilih secara selektif

Visi adalah suatu pandangan yang sifatnya masih umum (macro) tetapi mengandung arti yang sangat dalam dan memiliki makna yang sangat filosofis sehingga menjadi spirit, pendorong, dan kendali dalam mengejar suatu cita-cita yang ingin dicapai. Dalam konteks komunikasi maka visi adalah pesan. Pesan yang syarat akan kandungan makna filosofis di dalamnya, bermakna cita-cita dan harapan tentang situasi dan kondisi yang ingin dicapai di masa yang akan datang secara terukur dan realistis. Sehingga selain butuh komunikator yang tepat untuk menyampaikan pesan tersebut secara utuh dan benar kepada khalayak, juga harus dirumuskan secara tepat dengan tujuan agar semua khalayak bisa mengerti dan memahami pesan (visi) tersebut. Dalam hal ini, program studi Ilmu Komunikasi Fakultas Ilmu Sosial dan Ilmu Politik (FISIP) UIN Raden Fatah membutuhkan komunikator yang tepat untuk mengelolah, menyampaikan dan mengendalikan pesan (visi) Program Studi agar bisa diterima dan dimaknai oleh khayak, dalam konteks yang terbatas adalah mahasiswa.

Pesan lain juga bisa tercermin dari kegiatan-kegiatan yang diselenggarakan oleh Program Studi seperti, seminar nasional baik untuk kalangan mahasiswa dan dosen secara umum, perlombaan-perlombaan, event pekan komunikasi, kuliah umum komunikasi, kegiatan kerjasama dengan pihak luar, dan sebagainya. Harapan 
dari sekian banyak kegiatan-kegiatan tersebut adalah semakin menguatkan citra Prodi Ilmu Komunikasi di benak khalayak sebagai Program Studi yang memiliki banyak kegiatan bermanfaat untuk kepentingan mahasiswa dan dosen.

Selain pesan yang dibuat sifatnya disengaja, ada juga pesan yang muncul tanpa kesengajaan atau pesan yang memang melekat pada bawaan individu-individu tertentu, yang satu dengan yang lainnya berbeda. Misalnya dari cara berpakaian, gaya berbicara, dan semua perangkat-perangkat simbol yang digunakan antara dosen satu dengan dosen lain, pegawai satu dengan pegawai lain, mahasiswa satu dengan mahasiswa yang lain. Semuanya memproduksi pesan dan sulit untuk dikendalikan.

Mengenai pembentukan pesan bisa dilakukan oleh siapa saja, misalnya mahasiswa. Mereka dapat dengan mudah membuat sebuah pesan dan kesan untuk Prodi Ilmu Komunikasi sendiri. Seperti misalnya pesan yang disampaikan oleh Ananda salah satu mahasiswa Prodi Ilmu Komunikasi: "Pernah Pak, Adik mau masuk Ilkom, tapi setelah dia dikasih tau akreditasi $C$ dan peminatnya juga tidak banyak kecuali yang berminat itu karena sudah pilihan ke dua dan ketiga, dia mulai ragu. Jadi saya bilang masih banyak pilihan jurusan yang lain yang kira-kira lebih baik."

Ananda yang notabene adalah mahasiswi Program Studi Imu Komunikasi seperti menaru kecewa dari ungkapannya yang bercerita kepada adiknya bahwa akreditasi Ilmu Komunikasi masih "C" kemudian penegasannya "masih banyak pilihan jurusan yang lain yang kira-kira lebih baik." Dari pesan di atas sudah barang tentu penerima pesan akan menginterpretasi sesuai dengan isi pesan yang disampaikan. Bukan hanya pesan dari Annada, hal yang hampir mirip juga diungkapkan oleh Destri:"Iya pak, masih banyak yang berdapat komunikasi itu komputer, jadi dijelaskan aja komunikasi itu seperti ini. Klo ditanya uin udah punya apa, ya belum, lab juga belum ada. Sering cerita, lebih suka bercerita yang baik, kelebihan. Paling cerita kekurangan fasilitas belum baik, kelasnya masih numpangnumpang."

Sebagai seorang komunikator, Destri juga akan menyampaikan pesan kepada khalayak pada saat khalayak membutuhkan informasi tentang Program Studi Ilmu Komunikasi. Hanya saja dia lebih suka menyampaikan apa yang ada berdasarkan pengalaman dan ingatannya tentang Program Studi Imu Komunikasi.

Strategi komunikasi memberi arah dalam penyusunan-penyusunan pesan dalam sosialiasi program kegiatan, memberi pedoman bagi substansi sosialisasi program kegiatan, dan memastikan bahwa pelaksanaan sosialisasi atau 
penyampaian pesan mampu mengadvokasi dan mendorong semua partisipan komunikasi untuk mengembangkan lebih lanjut program komunikasi. Strategi pesan dalam perencanaan komunikasi memiliki dua fokus besar, yaitu strategi pesan komunikasi dalam rangka pencitraan dan dalam rangka membangun konsolidasi pelaksana program komunikasi, yaitu menggalang dukungan pemangku kepentingan agar program komunikasi dilaksanakan sesuai dengan rencana serta menumbuhkan partisipasi aktif khalayak dalam proses pelaksanaan kegiatan organisasi dalam hal ini adalah Program Studi Ilmu Komunikasi.

Dalam banyak temuan di lapangan, pengembangan strategi pesan yang bermuara pada pencitraan dan konsolidasi pelaksanan program komunikasi nampak belum sama sekali dilakukan, terbukti dengan pesan-pesan yang beredar di kalangan khalayak lebih condong kepada pesan yang tidak menunjukkan bahwa Prodi Ilmu Komunikasi tidak memiliki prospek yang bagus untuk menimba Ilmu Komunikasi, selain itu para komunikator tidak terjadi konsolidasi, semua bergerak sendiri-sendiri mengirimkan pesan kepada khalayak berdasarkan pengalaman dan fakta yang terjadi, tanpa memiliki kekompakan terhadap pesan apa yang harus selalu dibawa ke khalayak.

Semua tingkat dalam organisasi akan selalu mengandalkan komunikasi untuk; 1) mengembangkan visi bersama dari organisasi, 2) membangun dan menjaga kepercayaan dalam kepemimpinan organisasi, 3) memulai dan mengolah proses perubahan, 4) memperkuat identifikasi publik internal dengan organisasi (Sandeep, et al., 2005).

Sosialisasi program-program organisasi memerlukan perencanaan yang disusun oleh seluruh pemangku kepentingan dalam organisasi dan kerja sama dalam pelaksanaannya sehingga tidak membingungkan khalayak target. Dalam hubungan ini diperlukan konsolidasi operasional yang dilakukan di semua tingkat pemangku kepentingan tersebut. Sehingga menghasilkan pencitraan yang sama dan dukungan yang sesuai dengan kebutuhan suksesnya program komunikasi. Sosialisasi kepada khalayak internal maupun eksternal diarahkan agar

\section{Menentukan Media}

Untuk mendukung berlangsungnya proses pertukaran pesan jalinan hubungan di dalam organisasi, diperlukan saluran komunikasi yang tepat dan sesuai dengan kebutuhan. Pada umumnya dalam sebuah organisasi, saluran komunikasi yang digunakan ada dua jenis, yakni saluran tatap muka dan saluran bermedia.

Memilih media komunikasi harus mempertimbangkan karakteristik isi dan tujuan isi pesan yang ingin disampaikan, dan jenis media yang dimiliki oleh 
khalayak. Isi pesan maksudnya ialah kemasan pesan yang ditujukan untuk masyarakat luas dan kemasan pesan untuk komunitas tertentu. Untuk masyarakat luas, pesan sebaiknya disalurkan melalui media massa misalnya surat kabar atau televisi, dan untuk komunitas tertentu digunakan media selebaran atau saluran komunikasi kelompok. Pengetahuan tentang pemilihan media di kalangan masyarakat harus diketahui lebih dahulu berdasarkan hasil riset yang telah dilakukan. Hal ini penting untuk menghindari terjadinya pemborosan biaya, waktu, dan tenaga. Tidak ada gunanya memakai media televisi jika siaran yang dimaksud tidak diterima oleh masyarakat. Tidak ada artinya menggunakan media surat kabar untuk masyarakat yang tidak tahu membaca.

Sebenarnya dalam menentukan media jenis media yang akan digunakan, seringkali terjadi pergeseran. Hal ini disebabkan perkembangan media itu sendiri selalu berubah dan berkembang dari waktu ke waktu secara cepat. Misalnya media cetak (surat kabar, majalah, tabloid, buku), media elektronik (radio dan televisi), media luar ruang, dan media tradisional sudah digolongkan sebagai media lama (konvensional), sedangkan internet dan telepon seluler digolongkan sebagai media baruu (new media).

Dalam proses menentukan media, Program Studi Ilmu Komunikasi dalam proses berkomunikasi dengan khalayak internal dan eksternal menggunakan media yang sesuai dengan kebutuhan pesannya. Artinya media yang dipakai adalah media yang sesuai dengan kriteria-kriteria pesan yang akan disampaikan. Seperti yang dijelaskan oleh Ketua Program Studi Ilmu Komunikasi, Reza Aprianti. "Kita dalam memilih media gak ada yang seklek, harus media ini media itu gak, tergantung kebutuhan kita apa, siapa yang mau dijangkau, fleksibel ya, kadang kita bermedia di media massa baik itu koran atau televisi, yang rutin itu di internet dengan website kita, facebook juga walapun gak intens, group whatsapp iya juga. Media yang lain juga tatap muka, rapat, pertemuan dengan orang tua mahasiswa, dan yang paling utama adalah media kelas dalam pembelajaran."

Secara sepintas, perencanaan media yang dilakukan oleh Prodi Ilmu Komunikasi sudah cukup baik, karena dari semua media yang ada hampir semuanya digunakan dalam menyampaikan pesan. Namun karena keterbatasan sumber daya manusia dan finansial, penggunaan media tidak terlalu yang bisa menjangkau khalayak luas tidak terlau massif.

\section{Menentukan Penerima}

Penerima biasa disebut dengan istilah khalayak, sasaran, pembaca, pendengar, pemirsa, audience, decoder atau komunikan. Khalayak adalah salah satu aktor dari 
proses komunikasi. Karena itu unsur khalayak tidak boleh diabaikan, sebab berhasil tidaknya suatu proses komunikasi sangat ditentukan oleh khalayak. Oleh sebab itu, perencanaan khalayak menjadi sangat penting untuk dilakukan. Mengingat siapa saja bisa berpotensi menjadi khalayak dari proses komunikasi yang kita lakukan sehingga dipandang perlu untuk merumuskan siapa yang menjadi khalayak prioritas atau sasaran tepat dalam tujuan komunikasi yang kita rancang.

Penerima atau khalayak dalam studi komunikasi bisa berupa individu, kelompok, dan masyarakat. Menjadi tugas seorang komunikator untuk mengetahui siapa yang akan menjadi khalayaknya sebelum proses komuikasi berlangsung.

Ada tiga aspek yang harus diketahui seorang komunikator menyangkut khalayaknya, yakni aspek sosiodemografik, aspek profil psikologis, dan aspek karakteristik perilaku khalayak.

Dari aspek sosiodemografik, komunikator perlu memahami hal-hal berikut:

a. Jenis kelamin, apakah khalayak itu mayoritas laki-laki atau perempuan.

b. Usia, apakah khalayak umumnya anak-anak, remaja atau orang tua.

c. Populasi, apakah jumlah khalayak yang ada kurang dari 10 orang atau lebih dari 50 orang.

d. Lokasi, apakah khalayak umumnya tinggal di desa atau di kota.

e. Tingkat pendidikan, apakah mereka rata-rata sarjana atau hanya tamat sekolah dasar.

f. Bahasa, apakah mereka rata-rata bisa mengerti bahasa Indonesia atau tidak.

g. Agama, apakah semuanya beragama Islam atau ada yang beragama lain.

h. Pekerjaan, apakah mereka umumnya petani, nelayan, guru, atau pengusaha.

i. Ideologi, apakah mereka umumnya anggota partai tertentu atau tidak.

j. Pemilikan media, apakah mereka rata-rata memiliki pesawat TV, berlangganan surat kabar atau tidak.

Aspek profil psikologis, ialah memahami khalayak dari segi kejiwaan, di antaranya adalah sebagai berikut:

a. Emosi, apakah mereka rata-rata memiliki temperamen mudah tersinggung, sabar, atau periang.

b. Bagaimana pendapat-pendapat mereka.

c. Adakah keinginan mereka yang perlu dipenuhi.

d. Adakah selama ini mereka menyimpan rasa kecewa, frustrasi atau dendam. 
Dari aspek karakteristik perilaku khalayak, perlu diketahui hal-hal sebagai berikut:

a. Hobi, apakah mereka umumnya suka olahraga, menyanyi atau pelesiran.

b. Nilai dan norma, hal-hal apa saja yang menjadi tabu bagi mereka.

c. Mobilitas sosial, apakah mereka umumnya suka berpergian atau tidak.

d. Perilaku komunikasi, apakah kebiasaan mereka suka berterus terang atau tidak.

Dalam proses menentukan khalayak/penerima pada setiap program komunikasi ditemukan belum cukup maksimal. Prodi Ilmu Komunikasi beranggapan siapa saja yang bisa mengaskses informasi yang berasal dari Prodi Ilkom adalah penerima/khalayaknya. Hal ini bisa dilihat bagaimana Prodi Ilmu Komunikasi dalam merencanakan media. Pada saat Prodi merencanakan media, pada saat itu juga secara tidak langsung juga merencanakan dan menentukan khalayak.

Selama ini perencanaan khalayak Program Studi Ilmu Komunikasi lebih banyak fokus pada khalayak internal saja, yakni mahasiswa, pegawai dan dosen, itu pun masih belum maksimal. Masih sedikit upaya membidik khalayak eksternal, jika pun ada khalayaknya adalah para orang tua mahasiswa dan beberapa instansi saja. Konsolidasi dengan khalayak internal pun masih terbatas.

Program komunikasi yang dilakukan untuk khalayak mahasiswa adalah agar mereka mengerti dan memahami apa itu Ilmu Komunikasi serta prospeknya untuk masa depan mereka, memberi pembekalan baca tulis Al-Qur'an bagi mahasiswa yang belum bisa membaca Al-Qur'an yang sesuai dengan visi bahwa salah satu ciri Program Studi Ilmu Komunikasi yang ada di Fakultas Ilmu Sosial dan Politik Universitas Islam Negeri Raden Fatah adalah berkarakter Islam. Seperti kutipan dari Reza Aprianti sebagai berikut. "Kita sih berharap mahasiswa kita sebelum dan setelah tamat bisa memahami secara teori dan praktek Ilmu Komunikasi, gak hanya paham ilmunya saja tapi juga cerdas dalam tindakan komunikasi di masyarakat. Etika berkomunikasi menjadi baik untuk semua partner komunikasinya, makanya di Prodi kita ada mata kuliah komunikasi profetik, klo mereka sudah paham itu, saya yakin mereka akan menjadi komunikator yang kredibel dan bisa memengaruhi orang lain. Iya, jadi bukan sebatas menguasai ilmu saja, tapi juga menguasai dan mengamalkan tindakan komunikasi yang sesuai dengan ajaran Nabi Muhammad."

Dari kutipan di atas, Program Studi Ilmu Komunikasi berharap dari pesanpesan atau proses komunikasi yang dilakukan baik itu menggunakan media tatap muka, media massa, maupun media online diharapkan khalayak (mahasiswa) mampu menguasai Ilmu Komunikasi secara teoritis dan praktis secara Islami. 
Selain itu khalayak yang tidak boleh luput dalam proses komunikasi adalah tenaga pendidik dan tenaga kependidikan. Dosen dan pegawai harus selalu dilibatkan dalam proses komunikasi, selain karena mereka adalah khalayak (komunikan) mereka juga adalah penyampai pesan (komunikator). Salah sedikit dalam memperlakukan khalayak tersebut akibatnya akan sangat fatal dan menggangu iklim komunikasi. Dari beberapa hasil wawancara dan observasi di lapangan, peneliti memperoleh temuan banyak keluhan dari para dosen dan pegawai mengenai tidak adanya fasilitas untuk menjalankan tugas yang diberikan, tidak ada transparansi mengenai anggaran kegiatan, honor koreksi yang tidak diberikan jika tidak ditanya yang bersangkutan, ruangan yang panas dan sebagainya. Seperti pernyataan salah satu dosen berikut. "Kira-kira masuk akal dak, kita ditugaskan untuk mengerjakan borang, bikin jurnal tapi fasilitas komputer gak ada, dituntut untuk ada pengabdian masyarakat tapi harus dengan biaya sendiri. Kita ini sering diminta sempurna tapi pihak atasan tidak mau menyempurnakan pelayanan ke kita. Contoh lain yang sering bikin kecewa, uang koreksi ujian, semua dosen kan sudah ada jatah masing-masing, klo semua berkas sudah dikumpul harusnya tidak mesti ditanya/ditagih oleh dosen bersangkutan baru diberikan, harusnya tanpa ditanya harus sudah dibagikan. Apalagi klo sampai dosen nagih uangnya gak ada, atau orang yang pegang uang sedang keluar, masa mau ngambil uang gak seberapa harus bolak-balik, kadang kita malu sendiri seolah-olah perhitungan dengan uang."

Pernyataan di atas adalah masalah yang tidak boleh dianggap sepele. Dampaknya akan sangat memengaruhi jalannya organisasi dalam mewujudkan visi bersama. Dalam proses komunikasi harus dihindarkan ada pesan buruk yang muncul karena akan berkembang dan memengaruhi citra organisasi. Juga harus diminimalisir adanya khalayak yang merasa kecewa dan dirugikan, karena dia bisa bertindak sebagai penyampai pesan (komunikator) untuk khalayak lain.

\section{Mengevaluasi Umpan Balik}

Pengukuran efek (impact measurement) mencatat seberapa jauh hasil yang telah dicapai untuk masing-masing target khalayak maupun keseluruhannya sebagaimana yang dinyatakan dalam tujuan program. Kriteria khusus (spesifik) untuk mengevaluasi efek program komunikasi haruslah secara jelas dinyatakan dalam tujuan yang akan memandu persiapan program dan pelaksanaannya. Kebanyakan program komunikasi terdiri atas kegiatan pengiriman pesan guna meningkatkan pengetahuan, kesadaran dan pemahaman khalayak, baik khalayak internal maupun eksternal. 
Meningkatkan pengetahuan merupakan hal yang sangat penting sebelum timbulnya ketertarikan atau motivasi di kalangan khalayak yang pada akhirnya akan mendorong kepada tindakan (action). Apa yang diketahui atau tidak diketahui khalayak mengenai organisasi, tidak peduli dari mana mereka mendapatkan informasi, akan memengaruhi bagaimana mereka menilai, bersikap, dan bertindak terhadap organisasi dan pada akhirnya memengaruhi hubungan organisasi atau perusahaan dengan khalayaknya. Kunci untuk melaksanakan evaluasi mengenai apa yang diketahui khalayak sebagai hasil kegiatan komunikasi adalah dengan mengukur berbagai variabel pengetahuan, kesadaran, dan pemahaman khalayak sebelum program komunikasi mulai dilaksanakan dan membandingkannya dengan hasil pengukuran setelah program dilaksanakan.

Untuk menentukan apakah telah terjadi perubahan atas khalayak sasaran, maka harus dibuat perbandingan antara sekurangnya dua program komunikasi yang sama yaitu dengan mengulangi program bersangkutan atas khalayak yang sama atau serupa atau menerapkan program tersebut atas suatu kelompok kontrol yaitu mereka yang tidak terekspos oleh program komunikasi (Morrison, Ross, Kemp, \& Kalman, 2010).

Yang menjadi tugas berat dalam proses perencanaan komunikasi Program Studi Ilmu Komunikasi adalah sudah mulai muncul umpan balik yang setidaknya menjadi ancaman bagi terbentuknya citra yang buruk. Seperti misalnya, mayoritas mahasiswa belum menemukan identitas dan kebanggaan sebagai bagian dari Program Studi Ilmu Komunikasi. Masih banyak mahasiswa yang merasa terjebak bahwa harapan mereka masuk di Ilmu Komputer, ternyata salah ambil Jurusan. Ada juga yang beranggapan bahwa karena tidak lulus di universitas negeri lain atau karena tidak lulus jurusan pilihan pertama, karena di Prodi Ilmu Komunikasi diterima dengan terpaksa dijalani.

Maka dari umpan balik tersebut, sudah bisa ditarik kesimpulan bahwa Prodi Ilmu Komunikasi harus membuat perencanaan komunikasi atau program komunikasi yang membuat khalayak semakin bangga dan memberikan pemahaman bahwa mereka tidak salah bergabung di Program Studi Ilmu Komunikasi FISIP UIN Raden Fatah Palembang.

\section{Kesimpulan}

Berdasarkan hasil penelitian yang telah dilakukan, maka diperoleh kesimpulan bahwa Perencanaan Komunikasi adalah bagian dari manajemen strategis yang merencanakan secara terus menerus untuk setiap infrastruktur 
komunikasi; komunikator, pesan, media, khalayak dan evaluasi umpan balik secara tepat. Hasil akhir dari proses perencanaan komunikasi adalah semakin menguatkan citra positif sebuah institusi, dalam hal ini adalah Program Studi Ilmu Komunikasi. Citra posistif yang akan dibangun berdasarkan simbol-simbol yang sudah menjadi identitas komunikator dari rumusan visi dari Program Studi Ilmu Komunikasi. Terwujudnya bangunan citra positif Program Studi Ilmu Komunikasi akan berdampak pada semakin banyak khalayak yang menaruh kepercayaan kepada Program Studi Ilmu Komunikasi.

Melihat kondisi objektif perencanaan komunikasi di lingkungan Program Studi Ilmu Komunikasi, dapat diambil beberapa kesimpulan antara lain: 1) Peningkatkan ethos komunikator yang notabene sebagai source credibility di Program Studi Ilmu Komunikasi masih jauh dari kondisi ideal yang diharapkan. Hal ini bisa disebabkan oleh beberapa hal. Pertama, kurangnya pemahaman akan pentingnya membuat perencanaan komunikasi untuk membangun citra positif Program Studi. Kedua, belum ada konsolidasi dan penanaman kesadaran bahwa kapan saja dan di mana saja seorang komunikator harus menampilkan kredibiliasnya di hadapan khalayak publik. Ketiga, perlunya memasilitasi setiap komunikator agar semakin baik keahlian dan kompetensi bidang masing-masing. Karena khalayak akan melihat unsur ini dalam diri komunikator. Komunikator adalah simbol isntitusi. Baik buruknya citra institusi tergantung dari baik buruknya komunikator. 2) Mengomunikasikan pesan-pesan dari program komunikasi harus dilakukan secara terus menerus dan berkesinambungan. Terutama pesan-pesan yang bisa memengaruhi khalayak untuk mengubah perilaku dan tindakan sesuai dengan tujuan Program Studi. 3) Belum ada upaya mengoptimalkan seluruh media yang tersedia untuk mendukung program komunikasi. Padahal media sangat dibutuhkan untuk mendukung berlangsungnya proses pertukaran pesan ke dalam dan ke luar dalam organisasi. Program Studi Ilmu Komunikati harus melakukan optimalisasi potensi-potensi media yang ada untuk digunakan dalam proses komunikasi kepada khalayak luas. Mengingat pentingnya optimalisasi media, dipandang perlu untuk menunjuk petugas khusus yang bekerja untuk mengelolah media dan membagun media relations. 4) Khalayak adalah salah satu aktor dari proses komunikasi. Unsur ini dipandang belum maksimal diberdayakan oleh Program Studi Ilmu Komunikasi. Karena itu unsur khalayak tidak boleh diabaikan, sebab berhasil tidaknya suatu proses komunikasi sangat ditentukan oleh khalayak. Oleh sebab itu, perencanaan khalayak menjadi sangat penting untuk dilakukan. Mengingat siapa saja bisa berpotensi menjadi khalayak dari proses komunikasi yang kita lakukan sehingga 


\section{Ainur Ropik}

p-ISSN: 1412-1697; e-ISSN: 2477-3816

http://jurnal.radenfatah.ac.id/index.php/intizar

dipandang perlu untuk merumuskan siapa yang menjadi khalayak prioritas atau sasaran tepat dalam tujuan komunikasi yang dirancang. Dan yang paling mendasar bahwa hubungan dengan khalayak harus selalu dijaga. Diajak untuk bersama-sama membangun visi Program Studi, meminimalisir adanya rasa kecewa di benak khalayak, terlebih khalayak internal yang pada suatu titik akan menjelma menjadi komunikator dan menyampaikan perasaan kecewa tersebut kepada khalayak lebih luas. 
Ainur Ropik

Perencanaan Komunikasi Program Studi Ilmu Komunikasi

Fakultas Ilmu Sosial dan Ilmu Politik UIN Raden Fatah Palembang

\section{Daftar Pustaka}

Cangara, H. (2013). Perencanaan dan Strategi Komunikasi. Jakarta: Raja Grafindo Persada.

Kuswarno, E. (2009). Metodologi Penelitian Komunikasi. Bandung: Widya Padjadjaran.

Luft, J., \& Ingham, H. (1961). The johari window. Human Relations Training News, $5(1), 6-7$.

McCroskey, J. C. (1966). Ethos: A confounding element in communication research. United Kingdom: Taylor \& Francis.

Mehrabian, A. (1971). Nonverbal betrayal of feeling. Journal of Experimental Research in Personality.

Morrison, G. R., Ross, S. M., Kemp, J. E., \& Kalman, H. (2010). Designing effective instruction. , . John Wiley \& Sons.

Sandeep, T. C., Andrew, R., Homer, N. Z., Andrews, R. C., Smith, K., \& Walker, B. R. (2005). Increased in vivo regeneration of cortisol in adipose tissue in human obesity and effects of the 11 $\beta$-hydroxysteroid dehydrogenase type 1 inhibitor carbenoxolone. Diabetes, 54(3). 